\title{
Spatial and Multi-temporal Analysis of Deforestation and Quantification of the Remnant Forests on Porto Rico Island, Paraná, Brazil
}

\author{
João Batista Campos \\ Instituto Ambiental do Paraná - IAP. Av. Bento Munhoz da Rocha Neto, 16. - CEP 87.030-010 Maringá - Paraná - \\ Brazil
}

\begin{abstract}
The process of land occupation by the state of Paraná practically decimated its forests. Presently, only $7 \%$ from a total area of $83.41 \%$ is covered by forests. Most of them are now concentrated in the "Serra do Mar" and in the Iguaçu National Park. With regard to forest cover the most critical region is situated in the northwestern of the state with less than $1 \%$ of its area covered by forest. This restricted area mainly consists of conservation units and the islands of the high Paraná River floodplain. The present study consists of a spatial and multi-temporal analysis of deforestation and the quantification of the remnant forests on Porto Rico island $\left(22^{\circ} 45^{\prime} S ; 3^{\circ} 15^{\prime} \mathrm{W}\right)$, which have their occupation history linked to the colonization process of the region. Historical aerial photographs of this region were used and the relationship of deforestation with the process of colonization and social transformation of the region is discussed.
\end{abstract}

Key words: photogrammetry, alluvial forest, floodplain, forest.

\section{INTRODUCTION}

Originally, the state of Paraná had $83.41 \%$ of its area covered with forests (Maack, 1968). The process of territorial occupation of the state began from the Atlantic coast, reached the first plateau of Curitiba and rapidly developed on the second and third plateaux towards the Paraná river. The process practically decimated whole forests; currentlly only about $7 \%$ of the original forest cover remains (Fundação SOS Mata Atlântica 1992/93).

In the area of convergence of the high Paraná river floodplain, between the states of Paraná and Mato Grosso do Sul, the situation is more critical. Forests have been almost totally destroyed. The original forest covering the northwestern area of the state of Paraná doesn't surpass 1\%; in Mato Grosso do Sul deforestation already reached critical levels with only $42.2 \%$ of native vegetation in the whole state and $0.83 \%$ in the southern area (Fundação
SOS Mata Atlântica 1992/93; Fundação Ipardes, 1992).

The fluvial archipelago of the Paraná river between the states of Paraná and Mato Grosso do Sul is formed by a wide alluvial channel with low declivity $(7 \mathrm{~cm} / \mathrm{km})$ (Souza-Filho \& Stevaux, 1997), braided channels, hundreds of small lakes and more than 300 islands (Agostinho \& Zalewski, 1996) whose history is tied up with the territorial occupation of the state of Paraná .

Deforestation of the islands is related to the changes and social transformations that occurred in the area. The colonization process and use of the soil have dictated the rhythm and extension of the deforested areas. The process of deforestation is spatial and temporally evaluated from available historical aerial photographs of the area; the remaining forests on Porto Rico island are quantified and their relationships with the occupation process and land use in the area is discussed. 


\section{MATERIALS AND METHODS}

\section{Study area}

The area under analysis is one of the several islands that compose the fluvial archipelago of the High Paraná river. According to the most recent official map of the area (1980), the island had an area of 107.55 ha, lying approximately at $22^{\circ} 45^{\prime} \mathrm{S}$ and $53^{\circ} 15^{\prime} \mathrm{W}$. The climate of the area according to the Köeppen system is Cfa tropical-subtropical climate with hot summer (annual average of $22^{\circ} \mathrm{C}$ ) and annual medium precipitation of $1.500 \mathrm{~mm}$ (Campos \& CostaFilho, 1994). Altitude of the area is close to 230 $\mathrm{m}$ above sea level (Fig. 1).

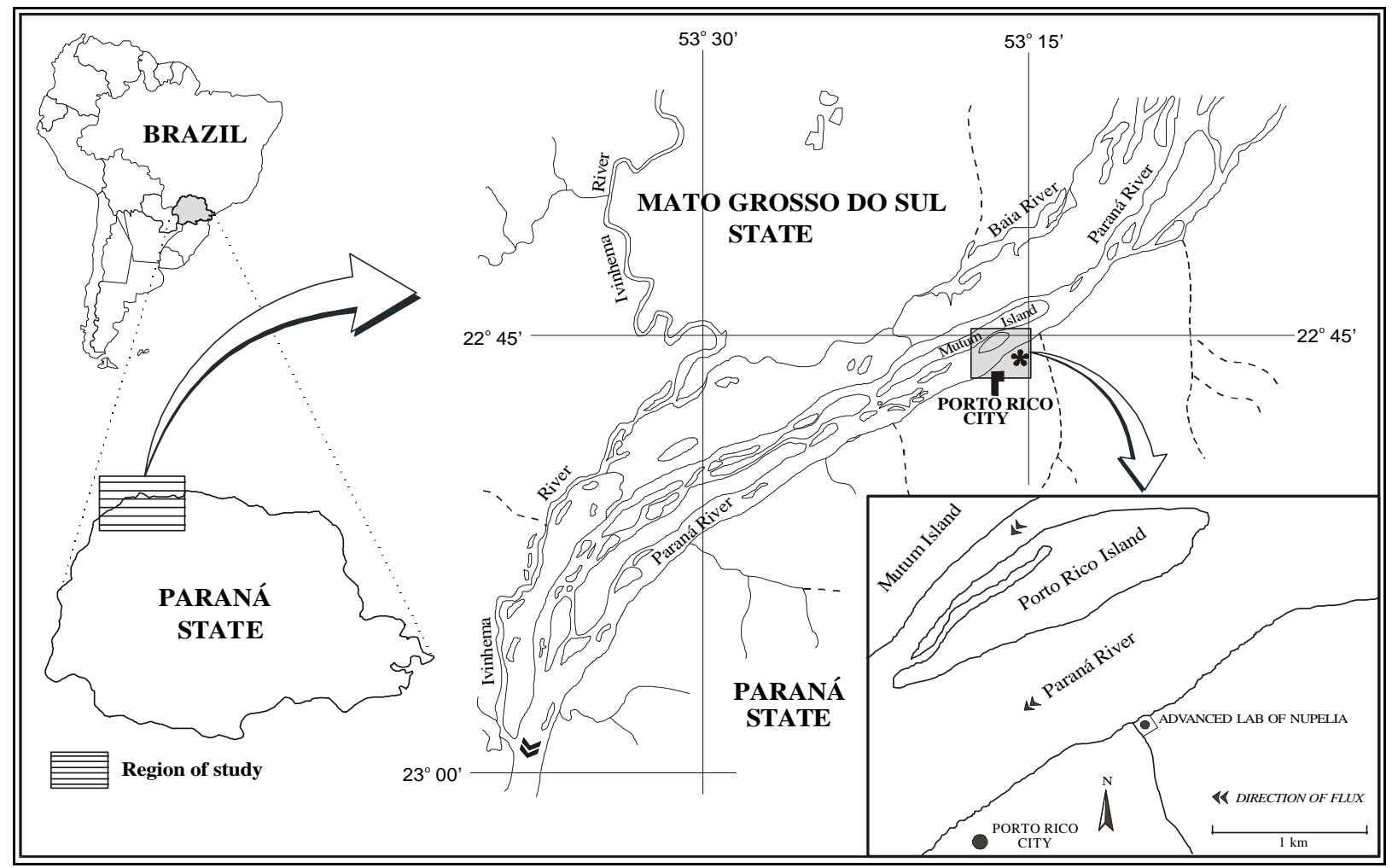

Fig. 1. Site of the area under analysis

The area is situated in the Semideciduous Seasonal Forest phytoecological region and the local vegetation is classified as Semideciduous Seasonal Alluvial Forest (IBGE, 1992; Campos \& Souza, 1997).

\section{Methodology}

Vertical metric aerial photographs obtained in the years 1952 (scale 1:25.000), 1965 (1:40.000), 1970 (1:50.000), 1980 (1:25.000) and 1996 (1:50.000) were used for multitemporal evaluation of deforestation and for the spatial quantification of the vegetation. Aerial photographs were analyzed and interpreted visually, with the aid of a stereoscope, and georeferenced to a cartographic basis (Loanda sheet, SF.22-Y-A-V DSG/IBGE, scale $1: 100.000)$.

The mapping of the identified vegetation types was elaborated by means of overlays of transparent sheets, fed into the SGI/INPE ${ }^{\circledR}$ program, with calculations of areas and perimeter limitations on the photos already digitally formated. The COREL-DRAW version 7.0 was used for final edition of the photo-maps and legends were placed according to the patterns related to the vegetation types identified in the aerial photographs.

Concerning the history of occupation and human dominion of the area under analysis, old maps, 
research projects reports and interviews with technicians responsible for the area's surveys were consulted.

\section{RESULTS AND DISCUSSION}

\section{History of occupation}

The occupation process of the territory of Paraná is a relatively recent occurrence. Until the beginning of this century, economic activity occurred in less than a third of the area of the state and was restricted and concentrated on the coast and in the south. Products that formed the basis of the state's economy, such as gold in the 17 th century and the extraction, industrialization and export of the mate tea and wood in the 19th and early 20th centuries, were exploited. As from 1930, an accelerated phase of the destruction of Paraná forests took place (Codesul, 1989) (Table 1).

Table 1. Historical process of deforestation and percentages of forest covering the state of Paraná (1890 - 1990).

\begin{tabular}{ccccc}
\hline Year & $\begin{array}{c}\text { Original forest } \\
\left(\mathrm{km}^{2}\right)\end{array}$ & Deforested area $\left(\mathrm{km}^{2}\right)$ & $\begin{array}{c}\text { Annual index of } \\
\text { deforestation }\left(\mathrm{km}^{2}\right)\end{array}$ & $\begin{array}{c}\text { Covering Forest } \\
(\%)\end{array}$ \\
\hline 1890 & 167,824 & - & - & $83.41^{1}$ \\
1930 & 129,024 & 38,800 & 970 & $64.12^{1}$ \\
1937 & 118,022 & 49,801 & 1,571 & $58.65^{1}$ \\
1950 & 79,834 & 87,990 & 2,938 & $39.67^{1}$ \\
1965 & 48,136 & 119,688 & 2,113 & $23.92^{1}$ \\
1980 & 23,943 & 143,881 & 1,613 & $11.90^{2}$ \\
1985 & 16,468 & 151,356 & 1,495 & $8.39^{3}$ \\
1990 & 15,030 & 152,794 & 287 & $7.59^{3}$ \\
\hline
\end{tabular}

${ }^{1}$ Maack (1968)

${ }^{2}$ Inventário de Florestas Nativas (IBDF) (Gubert-Filho, 1993)

${ }^{3}$ Fundação SOS Mata Atlântica (1992/93)

The original forests formerly covering $83.41 \%$ of the $201,203 \mathrm{~km}^{2}$ of the total area of Paraná (Maack, 1968) suffered a fast degradation. Since deforestation rhythm is linked to the colonization process and the expansion of the agricultural area, the highest peak observed in the annual index of deforestation occurred between 1937 and $1950\left(2,938 \mathrm{~km}^{2}\right)$. This fact coincided with the beginning of colonization of the northern part of Paraná, specifically in the area around the city of Londrina, founded in 1937, from which several districts and towns were dismembered, such as Apucarana (1943), Rolândia (1943), Arapongas (1947) and Mandaguari (1947).

The second largest annual index of deforestation $\left(2,113 \mathrm{~km}^{2}\right)$ occurred between 1950 and 1965 , and it was related to the process of colonization of the northwestern areas, or rather, with the foundation of the cities of Maringá (it became a district in 1951), Paranavaí (1951), Umuarama (1960); also in the southwestern region of
Paraná, where the cities of Cascavel (1951), Francisco Beltrão (1951), Pato Branco (1951) and Toledo (1951) were founded.

Between 1965 and 1985, deforestation indexes decreased from $1,613 \mathrm{~km}^{2} / \mathrm{year}^{-1}$ to 1,495 $\mathrm{km}^{2} / \mathrm{year}^{-1}$, although indexes remained relatively high. This was the era of the expansion of the agricultural frontier in the southwestern and northwestern regions of the state towards the Paraná river.

Between 1985 and 1990 when the agricultural frontier didn't exist any more and forest destruction was completed, this index decreased to $287 \mathrm{~km}^{2} / \mathrm{year}^{-1}$. In 1990 index of forest covering reached $7.59 \%$ of the state. Remaining forests were concentrated in conservation units, mainly on the coast in the Serra do Mar and in National Park of Iguaçu (Campos, in press). The northwestern area analyzed in this study has less than $1 \%$ of its area covered with forests (Fundação Ipardes, 1992). 
Initially, the colonization of the northwestern area was the initiative of the state's government when it founded the colony of Paranavaí in 1939. The town was elevated to district category in 1951 ; several districts were later on dismembered from the original town (Outline 1).

Outline 1. Origin of the district of Porto Rico, Paraná, Brazil, and year of foundation of the original districts (Source: SEMA 1997)

Paranaguá (1648) Coast

L Curitiba (1693)

L Castro (1789) $1^{\circ}$ Plateau

L Tibagi (1872)

L S. Jerônimo da Serra (1920) $2^{\circ}$ Plateau

L Jataí (1932)

L Londrina (1934)

L Apucarana (1943)

L Mandaguari (1947)

L Paranavaí (1951)

L Porto Rico (1963) $3^{\circ}$ Plateau

\section{Regional context of Porto Rico island}

The district of Porto Rico is situated on the bank of the Paraná river and has several islands whose occupation history is linked to that of the town of the same name.

The island under analysis is called Porto Rico island and is situated in front of the town of Porto Rico. By the 1983 agreement, INCRA (National Institute for Colonization and Agrarian Reform), the organization responsible for land regulatation in Brazil, transferred authority for the survey of land regulation on the islands of the Paraná river to the Institute of Land, Cartography and Forest (ITCF, currently Environmental Institute of Paraná, IAP). Because of boundary indefinition between the states of Paraná and Mato Grosso do Sul, technicians of ITCF established the deepest sounding of the river bed and thus, a criterion for the boundary between the two states.

According to Feuerschuette (1985), there was a juridical controversy regarding the islands of the Paraná river, or rather, the jurisdiction of limiting states over the islands. The author emphasized that the political and administrative jurisdiction exercised by the state of Paraná or by the frontier districts has been defined and consolidated throughout the years. Moreover, with regard to interstate boundaries, it was emphasized that river soundings criteria, establishing the bordering line of the state territories, would with great difficulty prevail on that of the political and administrative jurisdiction exercised by the Paraná state. This was especially true because of the great mobility of the channel as a result of the flood cycle and sand accumulation, both factors favouring constant changes. In a study on sedimentology in the high Paraná river floodplain, Stevaux (1994), contemplating a specific section in the area of Porto Rico, confirmed intense migration and changes in the soundings of the Paraná river.

Taking into consideration the fact that the history of occupation of the islands of the Paraná river, especially of the island under analysis, is linked to the state of Paraná, the discussion on the deforestation process and its connection to the Paraná State are rightly justified.

\section{Land occupation on Porto Rico island}

The first information regarding the occupation on the island, consisting of five houses (1964/66) was registered on the map of Loanda (SF.22-Y-A-V DSG/IBGE). According to SUCAM (now National Health Foundation FNS), ten houses and a population of 23 residents existed in the island in 1983. In 1987 the same registers reported that two houses and 
3 residents existed on the island. Same numbers were registered for 1993 (FUEM/CIAMBPADCT, 1993). Now, the island is occupied by two "presumed owners", extensive cattle raising, a single house occupied eventually by one of the proprietors who actually lives in the town of Porto Rico.

According to FUEM/CIAMB-PADCT (1993), the islands of the Paraná river became heavily occupied in the 70s when transformations in agriculture and cattle raising expansion expelled the small proprietors, partners, lessees and leaseholders of the rural areas of the districts in the neighbourhood of the Paraná river. On the other hand, changes in agricultural production, the "modernization" of agriculture, the substitution of the coffee plantations by cattle raising (the latter demanding heavy expansion of area) and the flood of 1982/83 provoked the expulsion and displacement of the population living on the islands of the Paraná river during the 80 s and, probably, land concentration.

In spite of the occupant decrease between 1987 and 1997, the degradation process and deforestation of the island didn't diminish, as may be seen below.

\section{Total area of Porto Rico island - Silt deposition and erosion}

The total area of the island related to dynamics of silt deposition and erosion by the Paraná river underwent several dimensional variations. In 1952, the reference year for the original forest covering in this study, the island had 101.31 ha. A coalescent sandbank in formation and the initial stage of colonization may be identified from the aerial photographs. The sandbank developed and fused itself to the island. In the 1965 aerial photograph, an increase of 12.4 ha to the total area might be noted, establishing the island's area at $113.71 \mathrm{ha}$.

The coalescent or fusing sandbank had already been identified by Santos et al. (1992). According to these authors, these sandbanks are diagonal appendixes to the islands and fused to the latter upstream. Such a fusion and the formation of a channel between the fused sandbank and the original bank of the island may be observed in the aerial photography of 1965.

From 1965, an erosion process began on the island with loss of area, reaching to the current level of 103.12 ha (Table 2).

Table 2. Total area, historical process of deforestation and percentage of forest covering for Porto Rico island (1952 - 1996).

\begin{tabular}{cccccc}
\hline Year & $\begin{array}{c}\text { Total area } \\
\text { (ha) }\end{array}$ & $\begin{array}{c}\text { Remaining } \\
\text { forest (ha) }\end{array}$ & $\begin{array}{c}\text { Deforested } \\
\text { area (ha) }\end{array}$ & $\begin{array}{c}\text { Annual deforestation } \\
(\text { ha })\end{array}$ & $\begin{array}{c}\text { Forest covering } \\
(\%)\end{array}$ \\
\hline 1952 & 101.31 & 93.92 & - & - & 92.08 \\
1965 & 113.71 & 47.91 & 65.80 & 5.06 & 42.13 \\
1970 & 111.87 & 26.78 & 85.09 & 3.86 & 23.94 \\
1980 & 107.55 & 18.28 & 89.27 & 0.42 & 17.00 \\
1996 & 103.12 & 6.17 & 96.95 & 0.48 & 5.89 \\
\hline
\end{tabular}

The speed of area loss may be associated with the occupation and deforestation process of the island. The interlacement of roots at several depths by forest vegetation in its several strata (arboreous, shrub and herbaceous) favoured the agglutination and cohesion of soil particles, increasing resistance to disaggregation with a consequent decrease of the erosive process. On the other hand, extensive cattle raising on the island caused the disembankment of the margins (when cattle went to the river to drink the water) and contributed to the erosion process. Perhaps popular culture picked up in one of the many meetings with the local population fits in very well: "Elsewhere, the riparian vegetation protects the water of the river from the soil that erosion carries away. It is different in the Paraná river. Riparian vegetation protects the soil of the islands from the waters of the river". This is a clear allusion to the protection that the riparian forest gives to the islands against the erosive effect of the river.

\section{Deforestation in Porto Rico island}

The historical process of deforestation in Porto Rico island may be visually observed in the 
photo-maps elaborated from aerial photographs

(Fig. 2). 
1952

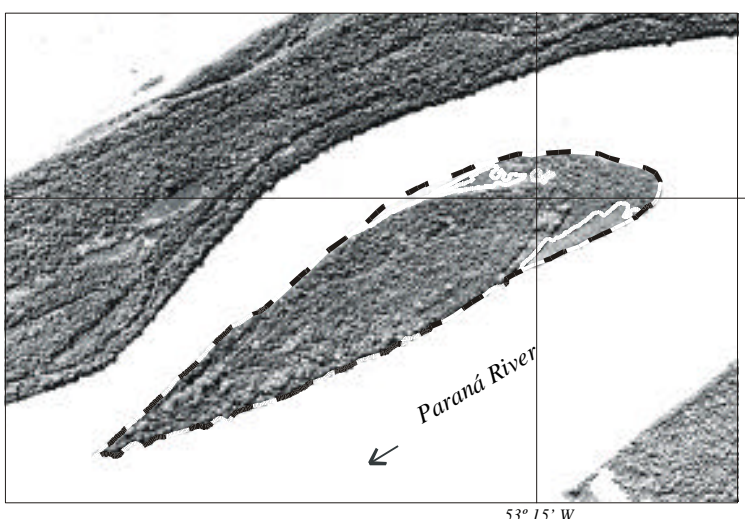

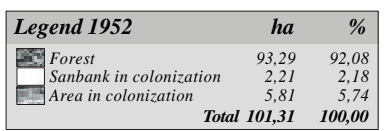

1965
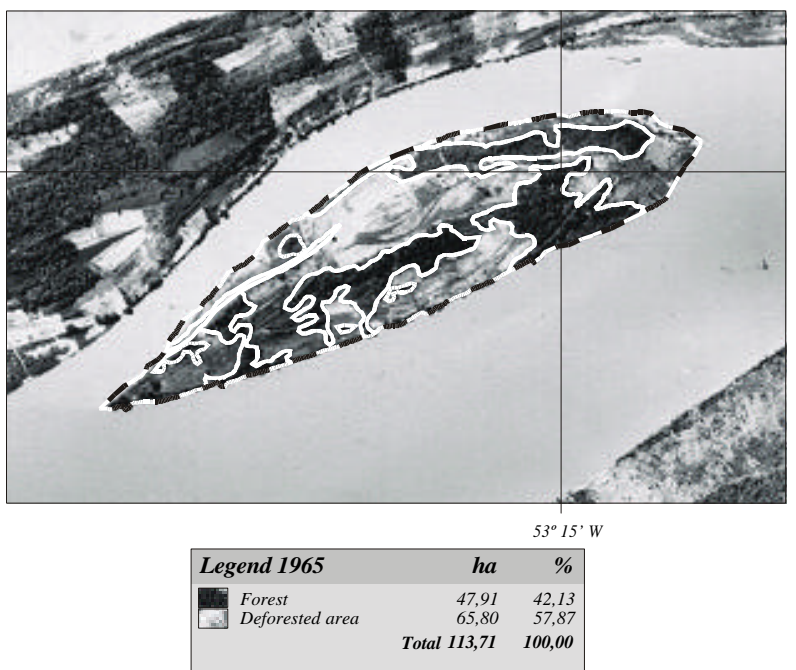

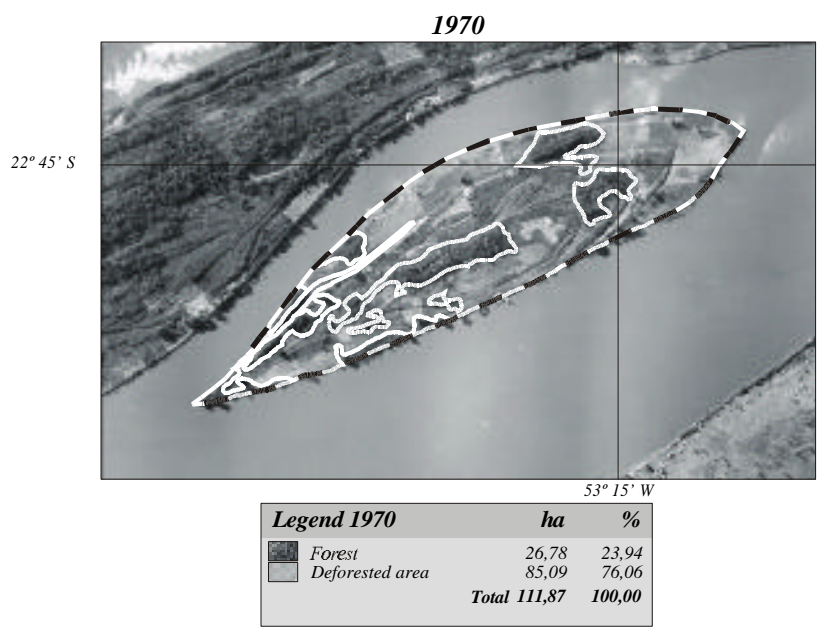

1980
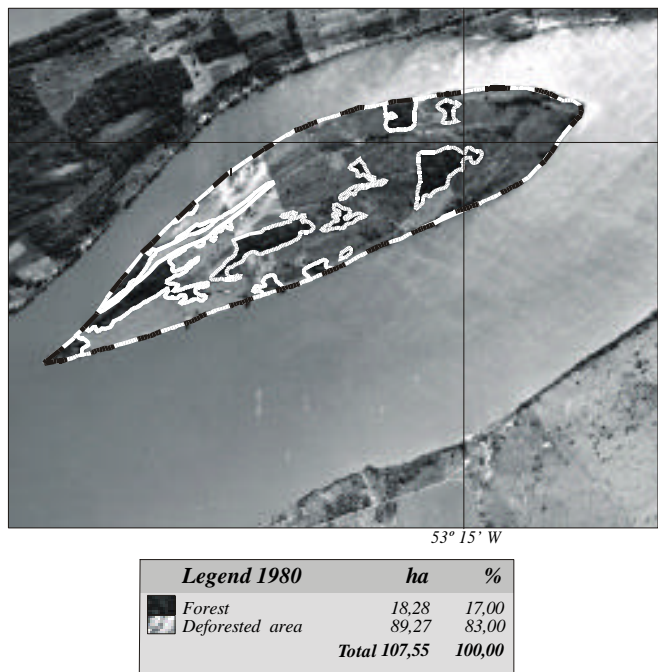

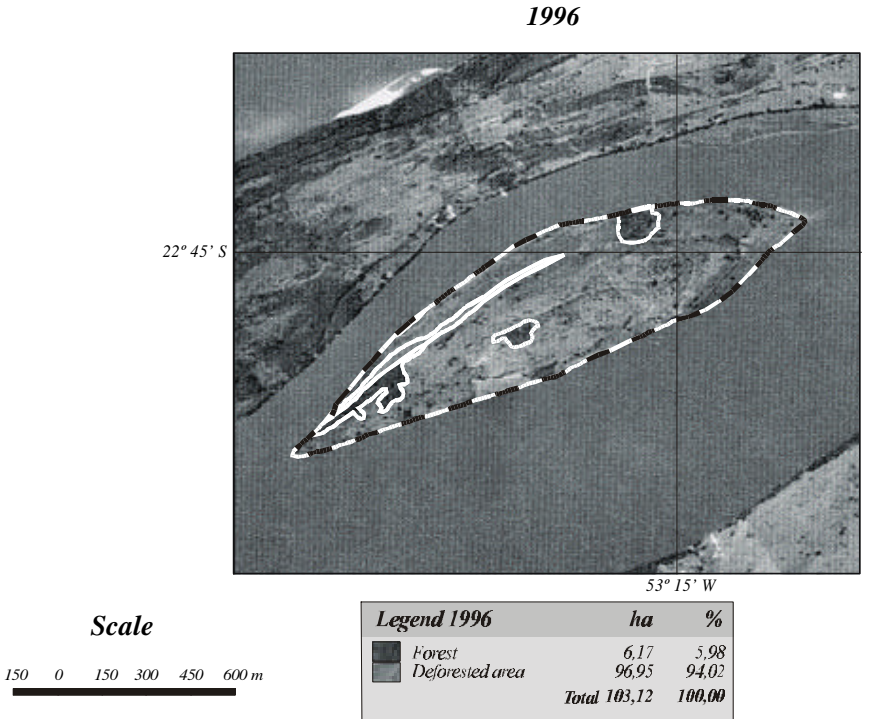

Fig. 2. Evolution of deforestation in the Porto Rico island for the years 1952, 1965, 1970, 1980 and 1996. 
From the photo-maps, it could be observed that Porto Rico island had all its original vegetation seemingly intact in 1952 when $92.08 \%$ of its total area was covered by forest and the remaining percentage was distributed between vegetation areas $(5.74 \%)$ and in sandbanks with incipient colonization (2.18\%).
Between 1952 and 1965, more than half of the island was already deforested (57.87\%). Between 1965 and 1970, deforestation process practically maintained the same rhythm (Fig. 3). a)

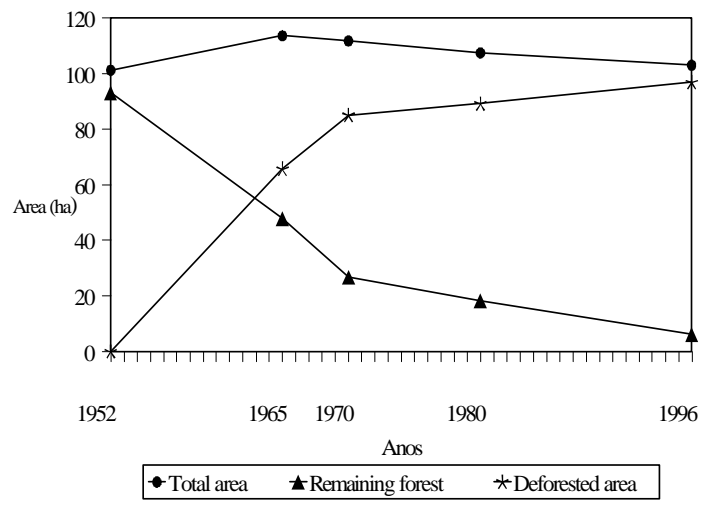

b)

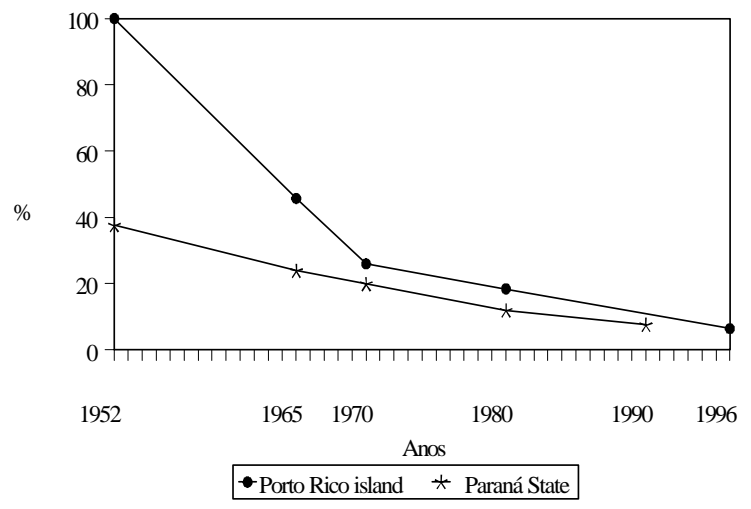

Fig. 3. a) Total area, deforested area and remaining forests in the Porto Rico island between 1952 and 1996 and b) percentage of remaining forests of the Porto Rico island and Paraná State (1952 - 1996).

Deforestation rhythm coincided with the colonization process and social transformations in the area. Rosa (1997) stated that between 1962 and 1967, due to the overproduction of coffee in Brazil and in order to maintain the product's international prices, the coffee shrub eradication policy was employed. Two hundred and five million coffee shrubs were uprooted. In the northwestern area of Paraná, sixty two million coffee shrubs were eliminated and pasture was introduced in the area. Since coffee plantation undoubtedly absorbed a great deal of labour, the eradication of the coffee shrubs expelled part of the population in the area as a consequence (Rosa, 1997 p.381). The islands of the Paraná river, considered as peripherical areas to agricultural exploration, served at that time as absorption areas for the population expelled from the rural production environment (FUEM/CIAMB-PADCT, 1993). This fact may explains the deforestation speed until 1970.

Between 1970 and 1996, the deforestation rhythm greatly decreased. This fact should be attributed to the exhaustion process of the remaining forest, which only occupied $25 \%$ of the area of the island in 1970. Between 1970 and 1996, 18.1 ha were deforested and at present only 3 florest fragments remain on the island, totalling 6.17 ha, which represented $5.98 \%$ of its area.

In terms of annual rhythm of deforestation, high values have been observed in the beginning of the occupation (up to 1970), with a decrease in subsequent years (Table 2 and Fig. 3a). In spite of a decrease in the number of occupants of the island between 1980 and 1996, deforestation maintained the same rhythm as that of the period comprising 1970 to 1980 . This was probably due to the expansion of deforested areas used for cattle raising.

Percentage of the remaining forests on Porto Rico island as compared to those in the state of Paraná, quickly decreased until the 70s. Later, it maintained a similar rhythm to that of the state, albeit at a slightly higher level. Projections indicated a steadily decreasing process of forest covering both in Paraná and on the island (Fig. 3b). 


\section{CONCLUSIONS}

Due to the physical smallness of the area, necessarily needing cartographic bases at large scales, aerial photographs have been a valuable instrument in the reconstruction of the history and true situation of the area's deforestation. Due to the available multi-temporal series and their high resolution level, aerial photographs are especially indicated for identification, quantification, spatial location and establishment of plans and directives for area reforestion and forest recovery in small and large enterprises. This study has been useful in analysing the historical evolution of the island's ocuppation: although it really began in 1952, deforestation on Porto Rico island quickly reached the levels of the state and followed closely the Paraná level of forest destruction.

The occupation process and deforestation of Porto Rico island seem to be related not only to the colonization process but also to the social changes occurring in the area, mainly the substitution of cultures that use a great amount of labour (for instance, coffee plantations) by activities that need area expansion for production with few employees (for instance, cattle raising). Consequently, land concentration and utilization excesses in the occupation of the agricultral frontier are brought about.

Considering that, according to the law, all properties should have at least $20 \%$ of their total area as forest reserve, besides those constituting permanent preservation, and since on Porto Rico island only $5.89 \%$ of its area is covered with forests, it could be concluded that Porto Rico island is being used illegally. Consequently, urgent action is needed towards the recovery of its destroyed forests.

\section{ACKNOWLEDGEMENTS}

Achnowledgements are due to SENAGRO Sensoriamento Remoto S.A., especially to Francisco Lothar Paulo Lange Jr. and Carmen Truite, for the collaboration in the making of the photo-maps and to Prof. Maria Cristina Rosa for the suggestions presented in the discussion of the paper. To Curse of Post-graduation in "Ecologia de Ambientes Aquáticos Continentais - Universidade Estadual de Maringá" and CNPq.

\section{RESUMO}

O processo de ocupação das terras do Paraná praticamente dizimou as florestas do Estado, que originalmente possuía $83,41 \%$ de sua área total coberta com florestas. Atualmente remanescem aproximadamente $7 \%$ da área com florestas, concentradas na Serra do Mar e no Parque Nacional do Iguaçu. Na região noroeste, a situação é mais crítica, com menos de $1 \%$ de sua área coberta por florestas, concentradas, principalmente, em unidades de conservação e nas ilhas da planície de inundação do alto rio Paraná. Esta planície é formada por uma ampla calha aluvial, com inúmeros canais, lagoas e ilhas, que têm sua história de ocupação ligadas ao processo de colonização na região. Neste trabalho, é realizada uma análise espacial e multi-temporal dos desflorestamentos e uma quantificação das florestas remanescentes da ilha Porto Rico $\left(22^{\circ} 45^{\prime} \mathrm{S}\right.$; $53^{\circ} 15^{\prime} \mathrm{W}$ ), por meio de fotografias aéreas históricas da região e discutidas as relações destes desflorestamentos com os processo de colonização e transformações sociais ocorridas na região.

\section{REFERENCES}

Agostinho, A.A.; Zalewski, M. (1996), A planície alagável do alto rio Paraná: importância e preservação, Maringá - PR : EDUEM. 100p.

Campos, J.B. (in press), Unidades de Conservação no Estado do Paraná: ações e contradições. Revista do Instituto Florestal Série Registros.

Campos, J.B.; Costa-Filho, L.V. (1994), Proposta técnica de implantação da área de proteção ambiental do Arquipélago de ilha Grande. Curitiba-PR : SEMA/IAP. 54p.

Campos, J.B.; Souza, M.C. (1997), Vegetação. In: A Planície de Inundação do Alto Rio Paraná: aspectos físicos, biológicos e socioeconômicos, ed. Vazzoler, A.E.A.M.; 
Agostinho, A.A.; Hahn, N.S. Maringá : EDUEM : Nupélia, 1997. pp. 331-342.

Codesul - Conselho de Desenvolvimento do Extremo Sul. (1989), Diretrizes para a preservação e conservação da natureza e para o desenvolvimento florestal na região sul do Brasil. Curitiba - PR, 60p.

Feuerschuette, R.C. (1985), Parecer $\mathrm{n}^{\circ}$. 146/84/PROJU - ITC. Revista de Direito Agrário e Meio Ambiente, 1, 150-152.

FUEM/PADCT-CIAMB. (1993), Estudos ambientais da planície de inundação do rio Paraná, no trecho compreendido entre a foz do rio Paranapanema e o reservatório de Itaipu. Maringá: Fundação Universidade Estadual de Maringá. 3v. (Relatório de pesquisa - Apoio PADCT-CIAMB).

Fundação Ipardes. (1992), Diagnóstico para a implantação de políticas para o setor florestal no Paraná. Curitiba - PR : Fundação Ipardes. 48p.

Fundação SOS Mata Atlântica/INPE. (1992/93), Atlas da evolução dos remanescentes florestais e ecossistemas associados do domínio da Mata Atlântica no período de 1985 - 1990. São Paulo : INPE. 20p.

Gubert-Filho, F.A. (1993), O desflorestamento do Estado do Paraná em um século. Paper presented at Conferência del Mercosur sobre Medio Ambiente e Aspectos Transfronteirizos, 61-69. Posadas, Argentina.

IBGE - Fundação Instituto Brasileiro de Geografia e Estatística. (1992), Manual técnico da vegetação brasileira. Rio de Janeiro : IBGE. 92p. (Série Manuais Técnicos em Geociências; 1).
Maack, R. (1968), Geografia Física do Estado do Paraná. Rio de Janeiro : J. Olympio. 442p.

Rosa, M.C. (1997), Processo de ocupação e situação atual. In: A Planície de Inundação do Alto Rio Paraná: aspectos físicos, biológicos e socioeconômicos, ed. Vazzoler, A.E.A.M.; Agostinho, A.A.; Hahn, N.S. Maringá : EDUEM : Nupélia, 1997. pp. 371-394.

Santos, M.L.; Fenandez, O.V.Q.; Stevaux, J.C. (1992), Aspectos morfométricos das barras de canal do rio Paraná. Boletim de Geografia, UEM-DGE, 10, 1, 11-24.

SEMA - Secretaria de Estado do Meio Ambiente e Recursos Hídricos do Paraná. (1997), Arquivo Gráfico Municipal do Estado do Paraná. Curitiba. 53p.

Souza-Filho, E.E.; Stevaux, J.C. (1997), Geologia e geomorfologia do complexo rio Baía, Curutuba, Ivinheima. In: A Planície de Inundação do Alto Rio Paraná: aspectos físicos, biológicos e socioeconômicos, ed. Vazzoler, A.E.A.M.; Agostinho, A.A.; Hahn, N.S. Maringá : EDUEM : Nupélia, 1997. pp. 3-46.

Stevaux, J.C. (1994). Geomorfologia, sedimentologia e paleoclimatologia do alto curso do rio Paraná (Porto Rico, Pr.). Boletim Paranaense de Geociências, 42, 97-112.

Received: June 20, 1998;

Revised: June 30, 1998; Accepted: September 14, 1998. 